\title{
Is it Still Necessary to Stop any Cow's Milk Protein Intake to Milk Allergic Infants with Non-Anaphylactic Events? A Case Report
}

Taan Aboudiab ${ }^{1 *}$, Khaled Zahreddine ${ }^{2}$, Souhaïb Al Hawari ${ }^{1}$, Lokombe Leke ${ }^{1}$ and Nicolas Kalach ${ }^{3}$

${ }^{1}$ Department of Neonatology, Saint Quentin Hospital, France

${ }^{2}$ Department of Biology, Antibes Juan-les-Pins Hospital, France

${ }^{3}$ Department of Gastro-enterology, Saint Vincent de Paul Hospital, France

Keywords: Cow milk protein; Allergy; Non anaphylactic events; Lymphocyte; Food tolerance

Abbreviations: CMPA: Cow's Milk Protein Allergy; CM: Cow's Milk; OFC: Oral Food Challenge; GERD: Gastro-Esophageal Reflux Disease; FPIES: Food Protein-Induced Enterocolitis Syndrome

Cow's Milk Protein Allergy (CMPA) presented with various clinical events ranging from anaphylaxis to digestive disorders through thrive failure. According to the last Committee on Nutrition of the French Society of Paediatrics report Cow's Milk (CM) elimination diet substitute by an extensively casein or whey hydrolyzed formula or more recently rice-based hydrolysates, represent the main therapeutic alternative, followed by an Oral Food Challenge (OFC) under hospital medical supervision between 6 and 12-month of age [1].

Yet, beside the anaphylactic events or serious discomfort that should not escape this rule, the remaining of the symptoms such as; resistant Gastro-Esophageal Reflux Disease (GERD) and/or oesophagitis to adequate treatment, and failure to thrive among others Food ProteinInduced Enterocolitis Syndrome (FPIES), in relation with CMPA have no vital risk for the infant.

The CMPA tolerance rate was $27.3 \%$ in patients with FPIES challenged at age 6 months, $63.6 \%$ at 10 months and $72.7 \%$ at $14-16$ months [2]. And also, first Follow-Up Oral Food Challenge (FU-OFC) was performed with CM in infantile FPIES at a mean age of 5.5 months, and found that only $22.2 \%$ were tolerant at this age [3].

The recent discovery of the role of the regulatory $\mathrm{T}$ cells (lymphocytes) (Treg), their involvement in tolerance induction and their influence on the TH1/TH2 balance [4], has led us to wonder about the usefulness of the total elimination of CM protein (CMP) products in infants during the first year of life with non-anaphylactic CMPA symptoms.

We have hypothesized that a threshold of tolerance to CM could exist, as we have previously demonstrated, in non-IgE mediated allergies, hypersensitive children to CM could tolerate fermented milk products in their vast majority [5]. Nowak-Wegrzyn et al. have shown that $75 \%$ of CMPA children could tolerate long heated milk [6].

To illustrate our hypothesis, we describe the history of a 25 days old newborn female, admitted in the neonatology ward for weight stagnation and non birth weight catching-up. She had 1 or 2 vomiting per a day. She was a full term infant, born at 38 weeks by a caesarean section, with a birth weight of $3460 \mathrm{gr}$ and a birth height of $50 \mathrm{~cm}$, without any atopic familial history.

Her clinical examination at day 25 of life was normal; in particular lack of signs of dehydration and her weight was 3440 gr. She was exclusively fed by a pre-thickened infant formula at a rate of $90 \mathrm{ml}$ six times per a day. Diuresis was normal without any biological ionic or infectious parameters disorders. Abdominal ultrasound had eliminated a pyloric stenosis.
The hypothesis of CMPA was then raised and specific CMP titers, KU/L, RAST Cap System ${ }^{\circledR}$, Phadia, Uppsala, Sweden, non-detectable values $\leq 0.10 \mathrm{KU} / \mathrm{L}$, was performed during her stay. A positive result was shown with Alpha-Lactalbumin titers of $1.73 \mathrm{KU} / \mathrm{L}$, BetaLactalbumin $5.96 \mathrm{KU} / \mathrm{L}$ and Casein $4.74 \mathrm{KU} / \mathrm{L}$. The standard infant formula was then mostly and not exclusively replaced by an extensively casein hydrolyzed formula while maintaining a small amount of her standard infant formula estimated at $10 \%$ ( $60 \mathrm{ml}=0,84 \mathrm{gr}$ of CMP) of the daily amount, divided into 2 times per a day in the morning and in the afternoon just before her casein extensively hydrolyzed formula ration intake.

Monitoring was then provided by her pediatrician followed by a transient marked weight catch up of 450 gr within 5 weeks, but thereafter, she presented new weight stagnation, diarrheal stools and frequent releases in favor to allergy to casein extensively hydrolyzed formula, indicating the use of amino acid formula (AAF). Although, that AAF is well known as more efficient than rice-based hydrolysates in this case, our patient, due to economic raisons, received rice-based hydrolysates without changing her daily CM-based standard infant formula intake.

The evolution will then benefit with weight gain of 550 gr in 18 days accompanied by a complete disappearance of all her pathological digestive signs, allowing the introduction of fermented follow up formula towards age of 5 months with a progressive increase of her original CM formula to get a complete reintroduction at the 6 months of age without resorting to hospitalization. We also showed that specific IgE-titers against CMP, Casein, Alpha-Lactalbumin, and BetaLactalbumin become undetectable, i.e. less than $0.01 \mathrm{KU} / \mathrm{L}$ at 5 months of age control.

This clinical case report appears of a particular interest to us, because if it is confirmed by other well structured prospective controlled randomized studies, it will pave the way for a new era in the management of non anaphylactic forms of CMPA in infants during the immune tolerance window period between 4-7 months of age [7],

*Corresponding author: Taan Aboudiab, Saint Quentin Hospital, Department of Neonatology, 1 Avenue Michel de l'Hopital, 02321 Saint Quentin Cedex, France, Tel: 0033323067203; E-mail: t.aboudiab@ch-stquentin.fr

Received October 25, 2013; Accepted November 27, 2013; Published December 03, 2013

Citation: Aboudiab T, Zahreddine K, Hawari SA, Leke L, Kalach N (2013) Is it Stil Necessary to Stop any Cow's Milk Protein Intake to Milk Allergic Infants with NonAnaphylactic Events? A Case Report. J Allergy Ther 4: 156. doi:10.4172/21556121.1000156

Copyright: (c) 2013 Aboudiab T, et al. This is an open-access article distributed under the terms of the Creative Commons Attribution License, which permits unrestricted use, distribution, and reproduction in any medium, provided the original author and source are credited. 
Citation: Aboudiab T, Zahreddine K, Hawari SA, Leke L, Kalach N (2013) Is it Still Necessary to Stop any Cow's Milk Protein Intake to Milk Allergic Infants with Non-Anaphylactic Events? A Case Report. J Allergy Ther 4: 156. doi:10.4172/2155-6121.1000156

Page 2 of 2

beside, the economic reduction related to the early reintroduction of standard CM-based infant and follow on formulas in hospitals such as is currently the case. We conclude that, in infants with CMPA non anaphylactic forms, an OFC tolerance protocol should be favored on a complete elimination diet as earlier as possible, leading to new immunotherapy strategy insights.

\section{References}

1. Dupont C, Chouraqui JP, de Boissieu D, Bocquet A, Bresson JL, et al. (2012) Dietary treatment of cows' milk protein allergy in childhood: a commentary by the Committee on Nutrition of the French Society of Paediatrics. Br J Nutr 107: 325-338

2. Hwang JB, Sohn SM, Kim AS (2009) Prospective follow-up oral food challenge in food protein-induced enterocolitis syndrome. Arch Dis Child 94: 425-428.
3. Powell GK (1978) Milk- and soy-induced enterocolitis of infancy. Clinical features and standardization of challenge. J Pediatr 93: 553-560.

4. Magnan A, Humbert M (2005) Is deficient tolerance the true paradigm for atopic diseases? Clin Exp Allergy 35: 1507-1510.

5. Aboudiab T, Léké L, Pautard JC, Béné MC, Prin-Mathieu C, et al. (2003) [Does non IgE-dependent sensitization to cow's milk proteins influence chronic cough and asthma in children?]. Arch Pediatr 10: 911-912.

6. Nowak-Wegrzyn A, Bloom KA, Sicherer SH, Shreffler WG, Noone S, et al (2008) Tolerance to extensively heated milk in children with cow's milk allergy. J Allergy Clin Immunol 122: 342-347.

7. Sansotta N, Piacentini GL, Mazzei F, Minniti F, Boner AL, et al. (2013) Timing of introduction of solid food and risk of allergic disease development: Understanding the evidence. Allergol Immunopathol (Madr) 41: 337-345. 